\title{
PENGARUH PSYCHOLOGICAL CAPITAL DAN KECERDASAN EMOSI TERHADAP STRES KERJA
}

\author{
Deden Dwi Haryadi \\ Fakultas Psikologi UIN Syarif \\ Hidayatullah Jakarta \\ deden.dwie@gmail.com
}

\author{
Akhmad Baidun \\ Fakultas Psikologi UIN Syarif \\ Hidayatullah Jakarta \\ Akhmad.baidun@uinjkt.ac.id
}

\begin{abstract}
This study aims to examine effects of psychological capital and emotional intelligence on work-related stress. 180 employees of PT. Dynaplast Mandiri were gathered as sample of this study using total sampling technique. Mulitiple regression analysis was used to analyse data with significance level of 0.05. result of this study indicates that there are significant effects of psychological capital and emotional intelligence on employees of PT. Dynaplast Mandiri's work-related stress with proportion of variance of $16.1 \%$ whilst the rest were explained by residual. Result of minor hypothesis testing indicates that self efficacy, resilience, and selfawareness have significant effects on work-related stress. Whilst optimism, hope, self-management, social awareness, and relationship management don't have significant effects on work-related stress.
\end{abstract}

Keyword: work-related stress, psychological capital, emotional intelligence, employees

\begin{abstract}
Abstrak
Penelitian ini bertujuan untuk mengetahui pengaruh psychological capital dan kecerdasan emosi terhadap stress kerja. Sampel dalam penelitian ini adalah karyawan PT. Dynaplast Mandiri sebanyak 180 orang. Jenis pengambilan sampel dalam penelitian ini adalah total sampling. Analisis data yang digunakan dalam penelitian ini adalah teknik analisis regresi berganda (Multiple Regression Analysis) pada taraf signifikansi 0,05. Hasil penelitian menunjukkan bahwa terdapat pengaruh yang signifikan psychological capital dan kecerdasan emosi terhadap stres kerja pada karyawan PT. Dynaplast Mandiri. Proporsi varians dari stres kerja yang dijelaskan oleh seluruh variabel bebas yaitu sebesar 16,1\%, sedangkan 83,9\% sisanya dipengaruhi oleh variabel lain di luar penelitian ini. Hasil uji hipotesis menunjukkan bahwa dimensi self-efficacy, resiliency dan self awareness memiliki pengaruh yang signifikan terhadap stres kerja. Sementara itu, dimensi optimism, hope, self-management, social awareness, dan relationship management tidak berpengaruh yang signifikan terhadap stres kerja.
\end{abstract}

Kata kunci: stres kerja, psychological capital, kecerdasan emosi, karyawan 


\section{PENDAHULUAN}

Stres kerja merupakan permasalahan yang perlu mendapatkan perhatian serius perusahaan. Stres kerja menjadi suatu persoalan yang serius bagi perusahaan karena dapat berdampak pada produktifitas dan kinerja dari karyawan dan perusahaan. Dapat dikatakan setiap orang pasti pernah mengalami stres saat bekerja. Akibat dari stres, sering kali apa yang dikerjakan hasilnya menjadi tidak maksimal, bahkan bisa berantakan. Menurut penelitian yang pernah dilakukan oleh Program Studi Magister Kedokteran Kerja, Fakultas Kedokteran Universitas Indonesia (FKUI) terhadap para pekerja kantor di Indonesia pada tahun 1990-an menunjukkan, sekitar $30 \%$ karyawan pernah mengalami stres di tempat kerja dengan beragam keluhan mulai dari yang ringan sampai berat. "Harus disadari, 15-30\% pekerja pernah mengalami masalah kesehatan jiwa," ujar Ketua Program Studi Magister Kedokteran Kerja, FKUI, dr Dewi S Soemarko, MS, SpOK, Selasa (19/7/2011) di Jakarta. Menurut Dewi, faktor risiko stres kerja dapat dipengaruhi dari lingkungan kerja (bising, tata ruang, suhu, pencahayaan), beban kerja, peran individu dalam organisasi dan faktor individu itu sendiri (Mikail, 2011).

Organisasi Kesehatan Dunia (WHO) sendiri telah menyatakan bahwa stres kerja telah menjadi epidemi di seluruh dunia. Menurut American Psychological Association (APA) tahun 1997, Amerika Serikat mengidentifikasi pekerjaan sebagai sumber stres yang paling signifikan karena beban kerja yang berat, ekspektasi pekerjaan yang tidak pasti dan waktu kerja yang lama (Avey, Luthans, \& Jensen, 2009). Penelitian yang luas selama bertahun-tahun telah difokuskan untuk mengidentifikasi stresor (Colligan \& Higgins, 2005). Serta mencari cara yang dapat digunakan oleh karyawan dan organisasi untuk secara efektif mengelola stres (Kram \& Hall, dalam Avey et al., 2009).

Menurut Avey et al., (2009) saat ini organisasi atau perusahaan selalu mencari berbagai cara untuk dapat membantu para karyawan dengan cara membuat lingkungan kerja yang selalu dapat membuat para karyawan merasa aman dan nyaman. Perusahaan juga semakin mengakui pentingnya sikap positif dan fokus berkonsentrasi kepada pengembangan potensi karyawan, daripada hanya berfokus terhadap hal negatif yang dilakukan karyawan dan berusaha untuk memperbaiki kelemahan karyawan. Sejumlah faktor juga berkontribusi terhadap stres kerja, mulai dari perubahan teknologi, tekanan dalam persaingan global, lingkungan kerja yang berbahaya serta intimidasi dari manager (Colligan \& Higgins, 2005).

Penelitian yang dilakukan oleh universitas Princeton menunjukkan bahwa mayoritas karyawan di semua tingkatan level pekerjaan merasakan stres di tempat kerja (Avey et al., 2009). Studi yang dilakukan oleh American Psychological Association (APA) pada tahun 2007 mencatat bahwa 50\% orang Amerika mengatakan stres yang dirasakan telah meningkat secara signifikan dalam lima tahun terakhir. Pekerjaan ditenggarai merupakan faktor penyebab stres terbesar bagi $74 \%$ warga Amerika, naik dari 59\% pada tahun 2006. Meskipun stres mempengaruhi karyawan saat ini, penting untuk dicatat bahwa stres tidak selalu 
menghasilkan hasil negatif seperti absensi dan penurunan kinerja. Stres juga dapat menghasilkan hasil yang positif, seperti peningkatan kreatifitas (Le Fevre, Matheny, \& Kolt, dalam Avey et al., 2009) dan peningkatan kinerja (Marino, 2004). Menurut Bernard dan Krupat (dalam Avey et al., 2009) meskipun manfaat yang mungkin didapat dari stres seperti peningkatan kreatifitas dan kinerja, tidak diragukan bahwa stres dapat menyebabkan masalah kesehatan, kecelakaan di tempat kerja, dan kejenuhan dalam bekerja.

Penelitian dari Goetzel dan rekan (dalam Avey et al., 2009) menunjukkan adanya hubungan antara stres kerja dan timbulnya penyakit. Penelitian tersebut menunjukkan stres kerja menjadi faktor yang berkontribusi secara spesifik terhadap penyebab utama kematian di Amerika Serikat dan pengeluaran untuk biaya berobat hampir 50\% lebih besar bagi pekerja yang memilki tingkat stres tinggi. Motowildo, Packard, dan Manning (dalam Avey et al., 2009) menyatakan stres kerja merupakan masalah bagi manajemen sumber daya manusia karena memiliki hubungan yang jelas antara stres yang dirasakan dengan kinerja karyawan. Bhagat dan rekan (dalam Avey et al., 2009) menyatakan stres dapat menghasilkan sesuatu yang tidak diinginkan oleh organisasi, seperti ketidakpuasan kerja, kelelahan, dan pengunduran diri karyawan.

Lazarus dan Folkman (1984) mengatakan bahwa seseorang menderita stres ketika percaya bahwa mereka kekurangan sumber daya yang diperlukan untuk menghadapi peristiwa atau kondisi yang sulit. Lazarus dan Folkman juga mencatat interaksi yang kompleks antara individu dan lingkungannya serta menekankan peran proses kognitif yang mungkin muncul sebagai faktor tersembunyi tetapi itu sangat mempengaruhi hasil dari peristiwa yang berpotensi menimbulkan stres. Penelitian yang dilakukan Costa dan McCrae (1990) juga telah mengakui bahwa terdapat faktor tambahan yang dapat mempengaruhi stres, seperti aspek kepribadian.

Selain kepribadian salah satu faktor lainnya adalah psychological capital yang mungkin berubah menjadi salah satu sumber daya yang penting seperti yang dikatakan oleh Lazarus dan Folkman (1984). Sumber daya yang diperlukan bagi karyawan untuk mengatasi peristiwa atau kondisi yang dapat menimbulkan stres di tempat kerja, sehingga dapat mengurangi gejala stres di tempat kerja. Lazarus (dalam Avey et al., 2009) menegaskan bahwa stres merupakan aspek yang tak terelakkan dari kehidupan dan sering memainkan peran kunci dalam mengembangkan kekuatan individu yang dibutuhkan tidak hanya untuk bertahan hidup, tetapi juga untuk berkembang. Lazarus berpendapat bahwa nilai yang cukup dapat diperoleh dengan lebih memahami bagaimana individu mengatasi beberapa realitas kehidupan yang keras dan mengabaikan stres negatif serta mendukung aspek manusia yang lebih positif. Lazarus (dalam Avey et al., 2009) secara khusus mengidentifikasi self-efficacy, optimism, hope, dan resiliency sebagai jalan yang mungkin diperlukan untuk meningkatkan pemahaman tentang bagaimana manusia beradaptasi terhadap stres. 
Konsep psychological capital ini telah dieksplorasi dan diteliti oleh Luthans, Youssef, dan Avolio (2007). Psychological capital sendiri ditandai oleh (1) percaya diri (self-efficacy) untuk menyelesaikan pekerjaan. (2) Memiliki pengharapan positif (optimism) tentang keberhasilan saat ini dan di masa yang akan datang. (3) Tekun dalam berharap (hope) untuk meraih keberhasilan. (4) Tabah dalam menghadapi berbagai permasalahan (resiliency) hingga mencapai sukses.

Self-efficacy didasarkan pada teori kognitif sosial Bandura (dalam Avey et al., 2009) yang dapat diterapkan di tempat kerja. Keyakinan terhadap self-efficacy mempengaruhi bagaimana individu memandang dan menafsirkan suatu peristiwa. Individu yang memiliki self-efficacy rendah mudah percaya bahwa upaya untuk mengatasi tantangan yang sulit adalah sia-sia sehingga lebih mungkin untuk mengalami gejala stres negatif, sementara individu dengan tingkat self-efficacy yang lebih tinggi melihat tantangan sebagai sesuatu yang dapat diatasi dengan berusaha.

Self-efficacy sendiri sangat terkait dengan pekerjaan yang berhubungan dengan kinerja. Bandura (dalam Avey et al., 2009) berpendapat bahwa kebanyakan stres manusia diatur oleh keyakinan tentang bagaimana mengatasi self-efficacy. Penelitian oleh Matsui dan Onglatco (dalam Avey et al., 2009) menemukan persepsi tentang kelebihan beban kerja akan dipengaruhi oleh apa yang dirasakan selfefficacy. Mereka menemukan bahwa karyawan perempuan yang memiliki tingkat self-efficacy rendah lebih cenderung mengalami stres oleh tuntutan pekerjaan yang berat dan tanggung jawab yang lebih tinggi dibandingkan dengan karyawan perempuan yang memiliki tingkat self-efficacy yang lebih tinggi.

Hubungan antara self-efficacy dan stres di tempat kerja juga telah ditunjukkan dalam penelitian terbaru dari pekerja di Hong Kong dan Beijing (Siu, Spector, \& Cooper, 2005). Penelitian lain tentang perawat yang memberikan perawatan kanker (Fillion et al., 2007). Self-efficacy juga telah terbukti menjadi salah satu kunci sukses bagi karyawan baru untuk bersosialisasi (Bauer et al., 2007) serta komitmen organisasi dan niat untuk mengundurkan diri karyawan (Harris \& Cameron, 2005).

Optimism, sebagaimana tercantum dalam psychological capital adalah realistis dan fleksibel. Optimism sebagai bagian dari psychological capital dihubungkan dengan pandangan positif tetapi bukan proses yang tidak terkendali tanpa evaluasi yang realistis. Seperti self-efficacy, optimism telah terbukti bisa menerima perkembangan melalui metode tiga langkah Schneider (dalam Luthans, Youssef, \& Avolio, 2007), yang meliputi melupakan masa lalu, penghargaan untuk saat ini, dan kesempatan melihat masa depan.

Schneider (dalam Avey et al., 2009) menunjukkan bahwa karyawan harus berhati-hati menilai kemampuan dengan berpegang pada perasaan bersalah atau rasa malu, karena perasaan negatif tersebut dapat membatasi kemampuan mereka untuk menghargai dan belajar dari situasi positif dan bahkan menghambat pengambilan keputusan di masa depan. Dalam analisis terhadap pekerja portofolio (wiraswasta yang bekerja untuk beberapa klien), Totterdell, Wood, dan Wall (2006) 
menemukan optimism menjadi faktor kunci dalam memoderasi hubungan antara karakteristik pekerjaan dan ketegangan dalam pekerjaan. Pekerja portofolio dengan tingkat optimism tinggi dianggap Totterdell et al., (2006), mampu mengerjakan semua pekerjaan yang diterimanya dan cenderung kurang mengalami gejala stres di tempat kerja.

Hope, menurut C. Rick Snyder (dalam Avey et al., 2009) umumnya digunakan dalam bahasa sehari-hari. Menurut Snyder dan rekan (dalam Avey et al., 2009), hope berasal dari kesuksesan (1) agency (tekad untuk mencapai tujuan) dan (2) pathways (perencanaan untuk mencapai tujuan). Dengan kata lain, hope terdiri dari willpower (agency individu, atau tekad untuk mencapai tujuan) dan pola pikir waypower (jalur alternatif dan rencana berkelanjutan untuk mencapai tujuan saat menghadapi rintangan). Penelitian Peterson dan Luthans (dalam Avey et al., 2009) menunjukkan bahwa manajer dengan tingkat hope yang lebih tinggi memiliki kinerja yang lebih baik dalam unit kerja dan peningkatan daya ingat serta bawahan yang lebih menghargai.

Sampai saat ini hubungan antara hope dan stres kerja sangat sedikit mendapat perhatian penelitian. Namun, terdapat bukti kuat dari penelitian tentang hope dalam konteks lain (misalnya, psikologi klinis dan atletik) menunjukkan hope yang mungkin memberikan individu sumber daya positif dalam situasi stres di tempat kerja. Snyder dan rekan (dalam Avey et al., 2009) menunjukkan bahwa hope memiliki korelasi negatif yang signifikan dengan kecemasan dan hasil penelitian menunjukkan tingkat hope individu dapat melindunginya dari persepsi terhadap kerentanan, kelonggaran kontrol, dan ketidakpastian.

Snyder (dalam Avey et al., 2009) beranggapan bahwa intervensi pelatihan dari dimensi hope telah terbukti berhasil dalam mendukung dan membangun tingkat hope individu. Pelatihan mengenai hope ditempat kerja sendiri baru mulai muncul. Hasil dari pelatihan ini berfokus pada perencanaan tujuan, persiapan, serta mengatasi berbagai rintangan dan dapat membantu manajer SDM di dalam mempengaruhi persepsi karyawan terhadap berbagai rintangan atau tantangan di dalam perusahaan (Luthans, Avey, \& Patera, 2008).

Resiliency, dapat dikatakan sumber daya positif paling penting untuk mengurangi stres kerja (Luthans, Youssef, \& Avolio, 2007). Pengembangan terhadap resiliency diperlukan untuk membantu individu pulih dari keterpurukan. Menurut Tugade dan Fredrickson (dalam Avey et al., 2009), berbagai metode terbukti sukses dalam membangun resiliency, termasuk menggunakan emosi positif dan mendorong peningkatan serta pengembangan diri. Seseorang dengan resiliency ditandai oleh kesetiaan terhadap realitas (Coutu, 2002) dan upaya mengembangkan resiliency didasari pada penilaian realistis serta menciptakan strategi coping ketika terjadi kemunduran. Penelitian terbaru Youssef \& Luthans (2007) menunjukkan hubungan positif antara resiliency dan kinerja, kepuasan kerja, komitmen organisasi, serta kebahagiaan kerja karyawan.

Luthans, Avolio, Avey, dan Norman (2007) dalam penelitiannya menyimpulkan bahwa terdapat hubungan yang positif diantara keempat dimensi 
dalam psychological capital dengan kinerja dan kepuasan kerja karyawan. Sedangkan Avey, Patera dan West (2006) menyimpulkan bahwa psychological capital berpengaruh terhadap absenteism (ketidakhadiran), yaitu ketika nilai psychological capital seseorang semakin tinggi, maka tingkat absenteeism semakin rendah. Luthans, Norman, Avolio, dan Avey (2008) juga melakukan penelitian dengan hipotesis yaitu psychological capital sebagai mediasi hubungan antara iklim pendukung dengan performa kerja karyawan. Hasil dari penelitian ini menyatakan bahwa psychological capital benar mempengaruhi atau sebagai mediasi hubungan antara iklim pendukung dengan performa kerja karyawan.

Selain Psychological Capital terdapat beberapa aspek yang juga penting di dalam mengurangi atau bahkan menghilangkan stres yang dialami oleh karyawan di tempat kerja, salah satunya adalah kecerdasan emosi. Kecerdasan emosi sendiri berpengaruh terhadap kesehatan karyawan dan akan berdampak terhadap kinerja karyawan di dalam perusahaan. Kesehatan sendiri menurut Organisasi Kesehatan Dunia (WHO), sebagai "bio-psiko-sosial" dan kesejahteraan individu (Aghusto Landa, Lopez-Zafra, Berrios Martos, \& Aguilar-Luzon, 2008). Sehubungan dengan pengaruh kecerdasan emosi kepada kesehatan, Ciarrochi, Deane, dan Anderson (2002) menunjukkan bahwa kecerdasan emosi memiliki peran mediasi dalam hubungan antara kesehatan mental dan stres.

Konsep kecerdasan emosi sendiri pertama kali diperkenalkan oleh Salovey dan Mayer (1990). Namun, Daniel Goleman yang mengenalkan topik tersebut dalam bukunya yang berjudul "Emotional Intelligence." Setelah publikasi awal, beberapa penulis mengeksplorasi konsep dengan model teoritis yang berbeda (Parker, Taylor, \& Bagby, dalam Aghusto et al., 2008). Dua pendekatan utama muncul: model campuran, menggabungkan kemampuan emosional dengan dimensi kepribadian seperti optimisme dan kemampuan motivasi diri dan model kemampuan, berfokus pada bagaimana individu memproses informasi emosional serta menganalisis kemampuan yang diperlukan untuk pemrosesan tersebut (Brackett \& Salovey, dalam Aghusto et al., 2008).

Berdasarkan studi yang dilakukan oleh Sy, Tram, dan O'Hara (dalam Aghdasi, Kiamanesh, \& Ebrahim, 2011) dan Nikolaou dan Tsaousis (dalam Aghdasi et al., 2011) menyatakan bahwa karyawan dengan kecerdasan emosi yang tinggi menghadapi stres kerja yang rendah dalam lingkungan pekerjaan mereka. Karyawan dengan kecerdasan emosi yang rendah cenderung kurang memiliki kesadaran diri. Mereka tidak mampu mengatasi perasaan sendiri dan memiliki terlalu banyak stres yang pada gilirannya dapat memberikan pengaruh negatif kepada kepuasan kerja mereka. Satu dari beberapa studi yang mengeksplorasi hubungan antara kecerdasan emosi dan stres kerja adalah studi dari Bar-On, Brown, Kirkcaldy, dan Thome (dalam Aghdasi et al., 2011) yang meneliti hubungan antara variabel dalam kelompok pekerjaan yang berbeda. Hasil penelitian menunjukkan hubungan negatif yang signifikan antara kecerdasan emosi dan stres kerja.

Bar-On dan rekan menyelidiki kecerdasan emosi dalam dua kelompok kerja yaitu petugas polisi dan personil paraprofessional. Hasil penelitian menunjukkan 
bahwa polisi memiliki tingkat kecerdasan emosi yang tinggi daripada kelompok lainnya. Hal tersebut menunjukkan polisi lebih menyadari perasaan dan memahami diri mereka sendiri, sehingga dapat lebih beradaptasi terhadap peristiwa yang menimbulkan stres, dan dapat memilih strategi untuk mengurangi gejala stres dengan lebih baik.

\section{TEORI DAN HIPOTESIS}

1. Stres kerja

Zimbardo dan rekan (dalam Colligan \& Higgins, 2005) mendefinisikan stres sebagai perubahan keadaan fisik atau mental seseorang dalam menanggapi situasi (pembangkit stres) yang menimbulkan tantangan atau ancaman. Salah satunya, pada saat kita dihadapkan dengan situasi yang menantang yang akan membutuhkan sejumlah besar upaya fisik atau mental. Stres juga merupakan pendorong sifat paling primitif manusia yaitu "fight or flight response." Stres sendiri dapat membantu seseorang mencapai tujuan dan mendorong mereka melalui situasi yang menantang serta stres juga dapat menjadi penyebab seseorang mengalami tekanan emosional yang signifikan dan penyakit fisik.

Ivancevich dan Matteson (dalam Luthans, 2011) mengatakan stres adalah respon adaptif, dimediasi oleh perbedaan individu dan proses psikologis, yang merupakan konsekuensi dari setiap tindakan eksternal (lingkungan), situasi, atau peristiwa yang menempatkan tuntutan psikologis dan fisik yang berlebihan pada seseorang. Robbins dan Judge (2013) mengatakan stres adalah suatu kondisi dinamis di mana seorang individu dihadapkan pada peluang, tuntutan, atau sumber daya yang terkait dengan apa yang dihasratkan oleh individu tersebut dan yang hasilnya dipandang tidak pasti dan penting. Stres lebih sering dikaitkan dengan tuntutan (demand) dan sumber daya (resources). Tuntutan merupakan tanggung jawab, tekanan, kewajiban, dan bahkan ketidakpastian yang dihadapi oleh individu di tempat kerja. Sumber daya adalah hal-hal yang berada dalam kendali seorang individu yang dapat digunakan untuk memenuhi tuntutan.

J.C. Quick \& Nelson (dalam Quick, Quick, Nelson, \& Hurrell, 1997) mengatakan bahwa stres kerja adalah stimulus yang dihasilkan pikiran dan tubuh akibat tuntutan fisik atau psikologis yang terkait dengan pekerjaan. Stres kerja sendiri telah dimuat dalam Health and Safety Executive Inggris (dalam Weinberg, Sutherland, \& Cooper, 2010) yang menyatakan bahwa stres kerja adalah reaksi negatif yang dimiliki seseorang terhadap tekanan yang berlebihan atau jenis lain dari tuntutan yang diberikan kepada mereka di tempat kerja. Beehr dan Newman (dalam Luthans, 2011) juga berpendapat bahwa stres kerja adalah suatu kondisi yang muncul akibat interaksi antara individu dengan pekerjaan mereka, dimana di dalamnya terdapat ketidaksesuaian karakteristik dan perubahan yang tidak jelas yang terjadi dalam perusahaan. 
2. Psychological capital

Konsep psychological capital menggabungkan human capital yaitu "what you know" dan social capital yaitu "who you know." PsyCap lebih fokus kepada "who you are" dan perkembangan perasaan yaitu "who you are becoming." PsyCap termasuk pengetahuan, keterampilan, kemampuan teknis, dan pengalaman karena ini "who you are" (Luthans, Youssef \& Avolio, 2007). Luthan dan rekan (2007) mendefinisikan psychological capital ini sebagai kapasitas positif psikologis yang dimiliki oleh setiap individu yang berguna untuk dapat membantu individu tersebut untuk dapat berkembang dan yang ditandai oleh: (1) percaya diri (self-efficacy) untuk menyelesaikan pekerjaan, (2) memiliki pengharapan positif (optimism) tentang keberhasilan saat ini dan di masa yang akan datang, (3) tekun dalam berharap (hope) untuk berhasil, dan (4) ketahanan dalam menghadapi berbagai permasalahan (resiliency) hingga mencapai sukses.

\section{Kecerdasan Emosi}

Salovey dan Mayer (1990) melihat emosi sebagai respon terorganisasi, melintasi batas banyak subsistem psikologis, termasuk fisiologis, kognitif, motivasi, dan sistem pengalaman. Menurut Luthans (2011), emosi adalah reaksi terhadap suatu objek, bukan suatu sifat. individu menunjukkan emosi ketika "senang tentang sesuatu, marah pada seseorang, takut akan sesuatu." Suasana hati, di sisi lain, tidak diarahkan pada suatu objek. Pernyataan Wechsler (dalam Salovey \& Mayer, 1990) bahwa kecerdasan adalah kapasitas keseluruhan atau global individu untuk bertindak secara sengaja, untuk berpikir secara rasional, dan untuk menangani secara efektif terhadap lingkungannya.

Mayer dan rekan (dalam Slaski \& Cartwright, 2003) mendefinisikan kecerdasan emosi sebagai kemampuan dalam mengenali makna emosi dan hubungannya serta memecahkan masalah yang dialami berdasarkan kemampuan diri sendiri. Kecerdasan emosi dalam kapasitas untuk merasakan emosi, mengasimilasi perasaan emosi yang terkait, memahami informasi dari emosi dan mengaturnya. Mayer dan rekan (dalam Slaski \& Cartwright, 2003), mengatakan bahwa kecerdasan emosi terdiri dari kemampuan yang berbeda (i) persepsi dan ekspresi emosi, (ii) mengintegrasikan emosi dengan pikiran, (iii) pemahaman dan menganalisis emosi, dan (iv) regulasi reflektif dari emosi. Pendekatan ini berfokus kepada fakta bahwa kecerdasan emosi sesuai dengan kemampuan pemrosesan informasi dari berbagai wilayah otak.

Bar-On dan Parker (dalam Slaski \& Cartwright, 2003) mendefinisikan kecerdasan emosi sebagai susunan multifaktorial emosi yang terkait, kemampuan pribadi dan sosial yang saling terkait yang mempengaruhi kemampuan diri sendiri secara keseluruhan untuk secara aktif dan efektif mengatasi tuntutan dan tekanan. Kemampuan ini meliputi (i) menilai diri sendiri secara cermat; (ii) kemampuan merasakan dan memahami emosi sendiri dan emosi orang lain; (iii) kemampuan untuk membentuk dan mempertahankan hubungan intim; (iv) kemampuan untuk mengekspresikan dan mengelola emosi; (v) kemampuan untuk mengontrol diri; 
(vi) kemampuan untuk memvalidasi pemikiran dan perasaan seseorang; (vii) kemampuan untuk menangani perubahan dan memecahkan masalah secara efektif. Kemampuan tersebut dapat dikonseptualisasikan lebih sebagai kompetensi emosi daripada kecerdasan bawaan. Daniel Goleman (dalam luthans, 2011) mendefinisikan kecerdasan emosi sebagai kapasitas untuk mengenali perasaan diri sendiri dan orang lain, untuk memotivasi diri sendiri, dan untuk mengelola emosi dengan baik dalam diri sendiri dan dalam berhubungan dengan orang lain.

\section{METODE PENELITIAN}

Populasi dalam penelitian ini yaitu karyawan PT. Dynaplast Mandiri yang berjumlah 180. Karakteristik populasi dalam penelitian ini meliputi: (a) Karyawan PT. Dynaplast Mandiri baik itu karyawan tetap maupun kontrak, (b) Pendidikan minimal SMA atau yang sederajat, (c) Bersedia menjadi responden penelitian ini. Peneliti mengambil sampel dari seluruh populasi karyawan PT. Dynaplast Mandiri berjumlah 180 orang. Teknik pengambilan sampel yang digunakan dalam penelitian ini yaitu teknik total sampling. Digunakan teknik total sampling dikarenakan peneliti menggunakan seluruh populasi karyawan yang berada di bawah level manager sebagai sampel penelitian.

\section{HASIL PENELITIAN}

\section{Analisis regresi variabel penelitian}

Langkah pertama peneliti menganalisis besaran $R$ square untuk mengetahui berapa persen (\%) varians pada DV yang dijelaskan oleh IV. Untuk tabel $R$ square, dapat dilihat sebagai berikut:

\section{Tabel 1}

Model Summary R-Square

\begin{tabular}{ccccc}
\hline Model & $\mathbf{R}$ & R Square & $\begin{array}{c}\text { Adjusted R } \\
\text { Square }\end{array}$ & $\begin{array}{c}\text { Std. Error of } \\
\text { the Estimate }\end{array}$ \\
\hline 1 & $0,401^{\mathrm{a}}$ & 0,161 & 0,122 & 7,92163 \\
\hline $\begin{array}{c}\text { Predictors: } \\
\text { management, social awareness, relationship management }\end{array}$ &
\end{tabular}

Dari tabel 1 di atas, perolehan $\mathrm{R}$ square sebesar 0,161 atau $16,1 \%$. Artinya, terdapat sebesar $16,1 \%$ bervariasinya stres kerja pada subjek penelitian dipengaruhi oleh semua $I V$ dalam penelitian ini, sedangkan sisanya sebesar $83,9 \%$ dipengaruhi oleh variabel lain di luar penelitian ini. Kemudian dilakukan uji $\mathrm{F}$ untuk menganalisis pengaruh dari keseluruhan $I V$ terhadap stres kerja. 
Tabel. 2

Model Summary R-Square Independet Variable I \& Independent Variable II

\begin{tabular}{clrrr}
\hline Model & R & R Square & Adjusted R Square & $\begin{array}{c}\text { Std. Error of the } \\
\text { Estimate }\end{array}$ \\
\hline 1 & 0,348 & 0,121 & 0,101 & 8,01559 \\
2 & 0,401 & 0,161 & 0,122 & 7,92163 \\
\hline
\end{tabular}

Predictors: (Constant), self-efficacy, optimism, hope, resiliency,

Predictors: (Constant), self-efficacy, optimism, hope, resiliency, self awareness, self management, social awareness, relationship management

Peneliti juga melihat besaran $R$ square untuk mengetahui berapa persen (\%) varians DV yang dijelaskan oleh setiap IV. Dari tabel 2 dapat kita lihat bahwa perolehan $R$ square pada variabel psychological capital sebesar 0,121 atau $12,1 \%$. Artinya proporsi varians dari stres kerja yang dijelaskan oleh variabel psychological capital adalah sebesar 12,1\%, sedangkan $87,9 \%$ sisanya dipengaruhi oleh variabel lain di luar penelitian ini. Sedangkan, perolehan $R$ square pada variabel kecerdasan emosi sebesar 0,161 atau $16,1 \%$. Artinya proporsi varians dari stres kerja yang dijelaskan oleh variabel kecerdasan emosi adalah sebesar 16,1\%, sedangkan 83,9\% sisanya dipengaruhi oleh variabel lain di luar penelitian ini.

Tabel 3

Tabel Anova

\begin{tabular}{lccccc}
\hline \multicolumn{1}{c}{ Model } & Sum of Squares & df & Mean Square & F & Sig \\
\hline Regression & 2058,025 & 8 & 257,253 & 4,100 & .000 \\
Residual & 10730,634 & 171 & 62,752 & & \\
Total & 12788,659 & 179 & & & \\
\hline Predictors: (Constant), self-efficacy, optimism, hope, resiliency, self awareness, self
\end{tabular}
management, social awareness, relationship management

Dependent Variable : stres kerja

Berdasarkan tabel 3 di atas, dapat dilihat bahwa nilai p (Sig) pada kolom paling kanan adalah 0.000 dengan nilai $p<0.05$, maka hipotesis nihil yang menyatakan tidak ada pengaruh yang signifikan dari keseluruhan $I V$ terhadap stres kerja ditolak. Artinya, bahwa ada pengaruh yang signifikan dari psychological capital yang terdiri dari self-efficacy, optimism, hope, dan resiliency, dan kecerdasan emosi yang terdiri dari self-awareness, selfmanagement, social awareness, dan relationship management terhadap stres kerja.

Langkah berikutnya, peneliti melihat koefesien regresi dari setiap $I V$. Dengan ketentuan jika $t>1.96$, maka koefisien regresi tersebut signifikan dan $I V$ tersebut memiliki pengaruh yang signifikan terhadap stres kerja. Dari 
tabel 3 hanya koefesien regresi self-efficacy, resiliency, dan self-awareness yang signifikan mempengaruhi stres kerja, sedangkan koefisien regresi lainnya tidak. Adapun besarnya koefisien regresi dari setiap $I V$ terhadap stres kerja dapat dilihat pada tabel 3 .

Tabel 4

Koefisien Regresi

\begin{tabular}{|c|c|c|c|c|c|}
\hline \multirow[t]{2}{*}{ Model } & \multicolumn{2}{|c|}{$\begin{array}{c}\text { Unstandardized } \\
\text { Coefficients }\end{array}$} & & \multirow[t]{2}{*}{$\mathbf{T}$} & \multirow[t]{2}{*}{ Sig. } \\
\hline & $\frac{\mathrm{B}}{29353}$ & Std. Errror & Beta & & \\
\hline $\begin{array}{l}\text { Self-efficacy } \\
\text { Optimism } \\
\text { Hope } \\
\text { Resiliency } \\
\text { Self-awareness } \\
\text { Self-management } \\
\text { Social awareness } \\
\text { Relationship }\end{array}$ & $\begin{array}{l}0,256 \\
0.037 \\
0.076 \\
-0.192 \\
0.231 \\
0.043 \\
0.057 \\
-0.095\end{array}$ & $\begin{array}{l}0,094 \\
0,103 \\
0,101 \\
0,096 \\
0,093 \\
0,089 \\
0,094 \\
0.094\end{array}$ & $\begin{array}{r}0,246 \\
0,035 \\
0,073 \\
-0,178 \\
0,235 \\
0,041 \\
0,055 \\
-0,099\end{array}$ & $\begin{array}{r}2,718 \\
0,361 \\
0,745 \\
-2,009 \\
2,468 \\
0,481 \\
0,614 \\
-1,005\end{array}$ & $\begin{array}{l}0,000 \\
0,007 \\
0,719 \\
0,458 \\
0,046 \\
0,015 \\
0,631 \\
0,540 \\
0.316\end{array}$ \\
\hline management & & & & & \\
\hline
\end{tabular}

Dependent Variable: Stres kerja

Berdasarkan tabel 4 koefisien regresi di atas dapat dijelaskan persamaan regresi sebagai berikut $(*=$ signifikan):

Stres kerja $=29,353+(0,256) \quad$ self-efficacy $*(0,037)$ optimism + $(0,076)$ hope $-(0,192)$ resiliency $*+(0,231)$ self-awareness $*+(0,043)$ self-management $+(0,057)$ social awareness - $(0,095)$ relationship management $+e$

Penjelasan dari nilai koefisien regresi yang diperoleh pada setiap $I V$ sebagai berikut:

Variabel self-efficacy

Diperoleh nilai koefisien regresi sebesar 0,256 dengan signifikansi $0,007(p<0,05)$, artinya variabel self-efficacy secara positif berpengaruh signifikan terhadap stres kerja yang berarti semakin tinggi tingkat selfefficacy semakin tinggi stres kerja.

Variabel optimism

Diperoleh nilai koefisien regresi sebesar 0,037 dengan signifikansi 0,719 ( $p>0,05)$, artinya variabel optimism tidak berpengaruh secara signifikan terhadap stres kerja.

Variabel hope

Diperoleh nilai koefisien regresi sebesar 0,076 dengan signifikansi 0,458 $(\mathrm{p}>0,05)$, artinya variabel hope tidak berpengaruh secara signifikan terhadap stres kerja.

Variabel resiliency 
Diperoleh nilai koefisien regresi sebesar $-0,192$ dengan signifikansi $0,046(p<0,05)$, artinya variabel resiliency secara negatif berpengaruh signifikan terhadap stres kerja yang berarti semakin tinggi tingkat resiliency semakin rendah stres kerja.

Variabel self-awareness

Diperoleh nilai koesfisien regresi sebesar 0,231 dengan signifikansi 0,015 $(p<0,05)$, artinya variabel self-awareness secara positif berpengaruh signifikan terhadap stres kerja yang berarti semakin tinggi tingkat selfawareness semakin tinggi stres kerja.

Variabel self-management

Diperoleh nilai koefisien regresi sebesar 0,043 dengan signifikansi 0,631 $(\mathrm{p}>0,05)$, artinya variabel self-management tidak berpengaruh secara signifikan terhadap stres kerja.

Variabel social awareness

Diperoleh nilai koefisien regresi sebesar 0,057 dengan signifikansi 0,540 $(\mathrm{p}>0,05)$, artinya variabel social awareness tidak berpengaruh secara signifikan terhadap stres kerja.

Variabel relationship management

Diperoleh nilai koefisien regresi sebesar -0,095 dengan signifikansi 0,316 ( $p>0,05)$, artinya variabel relationship management tidak berpengaruh secara signifikan terhadap stres kerja.

\section{Pengujian proporsi varians independent variable}

Tabel 5

Proporsi Varians untuk Setiap Independent Variable

\begin{tabular}{|c|c|c|c|c|c|c|c|c|c|}
\hline \multirow[t]{3}{*}{ Model } & & \multirow{2}{*}{$\mathbf{R}$} & \multirow{2}{*}{$\begin{array}{c}\text { Adjusted } \\
\qquad \mathbf{R}\end{array}$} & \multirow{2}{*}{$\begin{array}{l}\text { Std. } \\
\text { Error } \\
\text { of the }\end{array}$} & \multicolumn{5}{|c|}{ Change Statistics } \\
\hline & & & & & $\stackrel{\mathbf{R}}{\mathbf{S}}$ & & & & \\
\hline & & Square & Square & Estimate & Changs & Change & df1 & df2 & \\
\hline & $0,319^{a}$ & & & & & & & 178 & \\
\hline & & 0.1 & & & 0.0 & 1.305 & & 177 & $\frac{0.255}{0.435}$ \\
\hline & $\frac{0.52}{0.34}$ & & & & & & & $\frac{110}{175}$ & $\frac{0.4}{0.1}$ \\
\hline & 0.3944 & 0.155 & & 7.88 & 0.034 & 1.07 & & $\frac{174}{172}$ & 0.009 \\
\hline & & & & & & & & & \\
\hline & $0,401^{\mathrm{h}}$ & 0.161 & 0.122 & 7.92163 & 0,005 & 1.009 & & 171 & 0,31 \\
\hline
\end{tabular}

Berdasarkan data yang ditampilkan pada tabel 5 dapat dijelaskan bahwa: Variabel self-efficacy memberikan sumbangan sebesar 10,2\% dalam varians 
stres kerja. Sumbangan tersebut signifikan dengan $F=20,123$ dan $\mathrm{df}=$ 1,178 .

Variabel optimism memberikan sumbangan sebesar $0,7 \%$ dalam varians stres kerja. Sumbangan tersebut tidak signifikan dengan $\mathrm{F}=1,305$ dan $\mathrm{df}=1,177$.

Variabel hope memberikan sumbangan sebesar 0,3\% dalam varians stres kerja. Sumbangan tersebut tidak signifikan dengan $\mathrm{F}=0,613$ dan $\mathrm{df}=$ 1,176 .

Variabel resiliency memberikan sumbangan sebesar 1,0\% dalam varians stres kerja. Sumbangan tersebut tidak signifikan dengan $\mathrm{F}=1,904$ dan df $=1,175$.

Variabel self-awareness memberikan sumbangan sebesar 3,4\% dalam varians stres kerja. Sumbangan tersebut signifikan dengan $\mathrm{F}=7,035$ dan $\mathrm{df}=1,174$.

Variabel self-management memberikan sumbangan sebesar $0,1 \%$ dalam varians stres kerja. Sumbangan tersebut tidak signifikan dengan $\mathrm{F}=$ 0,147 dan $\mathrm{df}=1,173$.

Variabel social awareness memberikan sumbangan sebesar $0 \%$ dalam varians stres kerja. Sumbangan tersebut tidak signifikan dengan $\mathrm{F}=$ 0,057 dan $\mathrm{df}=1,172$.

Variabel relationship management memberikan sumbangan sebesar 0,5\% dalam varians stres kerja. Sumbangan tersebut tidak signifikan dengan $\mathrm{F}$ $=1,009$ dan $\mathrm{df}=1,171$.

Berdasarkan pemaparan di atas, dapat disimpulkan bahwa dari delapan IV yaitu self-efficacy, optimism, hope, resiliency, self-awareness, self-management, social awareness dan relationship management, hanya dua IV yang signifikan sumbangannya terhadap stres kerja. Jika dilihat dari besarnya pertambahan $\mathrm{R}^{2}$ yang dihasilkan setiap kali dilakukan penambahan IV (sumbangan proporsi varians yang diberikan), dari dua IV tersebut dapat dilihat variabel yang paling besar memberikan sumbangan terhadap DV. Hal tersebut dapat diketahui dengan melihat $\mathrm{R}^{2}$ change, semakin besar maka semakin banyak sumbangan yang diberikan terhadap DV. Dari tabel 4.5 di atas, diketahui urutan IV yang signifikan memberikan sumbangan dari yang terbesar hingga terkecil adalah variabel self-efficacy dengan $\mathrm{R}^{2}$ change $10,2 \%$, variabel self-awareness dengan $\mathrm{R}^{2}$ change $8,1 \%$. 


\section{Diskusi}

Hasil penelitian menunjukkan ada pengaruh yang signifikan antara psychological capital dan kecerdasan emosi terhadap stres kerja. Hasil penelitian ini mendukung penelitian sebelumnya yang dilakukan oleh Avey et al. (2009) menemukan pengaruh yang signifikan dari variabel psychological capital terhadap stres dan intensi turnover. Secara terpisah hasil penelitian ini mendukung penelitian yang dilakukan oleh Chang \& Chang (2010) menemukan ada hubungan yang signifikan antara kecerdasan emosi terhadap stres kerja. Dari semua independent variable yang diteliti, terdapat tiga independent variable yang berpengaruh signifikan terhadap stres kerja, yaitu self-efficacy, resiliency, self-awareness. Sedangkan variabel lainnya seperti optimism, hope, self-management, social awareness, dan relationship management tidak memiliki pengaruh yang signifikan terhadap stres kerja.

Hasil penelitian dari variabel psychological capital menunjukkan bahwa terdapat pengaruh positif yang signifikan pada dimensi self-efficacy terhadap stres kerja. Artinya, semakin tinggi self-efficacy seseorang maka semain tinggi stres kerja. Hasil penelitian ini tidak sesuai dengan penelitian sebelumnya yang dilakukan oleh Herbert (2011) yang menyatakan bahwa self-efficacy menunjukkan pengaruh signifikan secara negatif terhadap stres kerja.

Self-efficacy sendiri merupakan keyakinan individu akan kemampuan yang dimiliki yang dapat mendorongnya untuk menjadi termotivasi dan sebagai jalan individu tersebut bertindak untuk dapat menjadi sukses melakukan suatu pekerjaan tertentu (Luthans, Youssef, \& Avolio, 2007). Keyakinan terhadap self-efficacy mempengaruhi bagaimana individu memandang dan menafsirkan peristiwa. Individu yang memiliki selfefficacy rendah mudah percaya bahwa upaya untuk mengatasi tantangan yang sulit adalah sia-sia sehingga lebih mungkin untuk mengalami gejala stres negatif, sementara individu dengan tingkat self-efficacy yang lebih tinggi melihat tantangan sebagai sesuatu yang dapat diatasi dengan berusaha (Bandura dalam Avey et al., 2009). Hasil yang berbeda ini dapat terjadi mungkin dikarenakan kepercayaan diri yang tidak realistis (unrealistic overconfidence) menyebabkan diri karyawan untuk senantiasa menantang diri sendiri dalam meraih tujuan yang lebih tinggi dalam pekerjaan, sehingga menyebabkan tingkat stres yang meningkat pada karyawan tersebut dan berakibat kepada menurunnya kinerja di tempat kerja. 
Hasil penelitian dari variabel psychological capital menunjukkan bahwa terdapat pengaruh negatif yang signifikan pada dimensi resiliency terhadap stres kerja. Artinya, semakin tinggi resiliency maka semakin rendah stres kerja. Penelitian ini sejalan dengan penelitian yang dilakukan Siu, Hui, Philips, Lin, Wong, dan Shi (2009) yang menyatakan resiliency berpengaruh signifikan secara negatif terhadap stres kerja dan kepuasan kerja. Resiliency merupakan kapasitas psikologis seseorang yang bersifat positif, dengan menghindarkan diri dari ketidakbaikan, ketidakpastian, konflik, kegagalan, sehingga dapat menciptakan perubahan positif, kemajuan dan peningkatan tanggung jawab (Luthans, Youssef, \& Avolio, 2007). Hubungan yang signifikan antara resiliency dan stres kerja dapat berasal dari fakta bahwa individu yang memiliki resiliency rendah cenderung memiliki kesulitan mengatur emosi negatif (yang disebabkan dari stres di lingkungan mereka) dan karenanya menunjukkan reaksi berlebihan terhadap peristiwa sehari-hari yang penuh stres (Ong et al., dalam Herbert, 2011). Semakin banyak studi menunjukkan bahwa perbedaan individu dalam resiliency dapat mempercepat pemulihan dari situasi stres. Serangkaian studi eksperimental dan perbedaan individu, Fredrickson dan rekan (dalam Herbert, 2011) menemukan bahwa individu dengan resiliency yang tinggi dapat memulihkan fisiologis dan emosional yang lebih cepat dari stres.

Hasil penelitian dari variabel kecerdasan emosi menunjukkan bahwa terdapat pengaruh positif yang signifikan pada dimensi self-awareness terhadap stres kerja. Artinya, semakin tinggi self-awareness seseorang maka semain tinggi stres kerja. Hasil penelitian ini sesuai dengan penelitian yang dilakukan Salim dan Nasir (2010) yang menyatakan self-awareness berpengaruh signifikan secara positif terhadap stres kerja. Self-awareness merupakan kemampuan untuk mengenali perasaan saat perasaan tersebut terjadi (Cherniss \& Goleman, 2001). Individu yang memiliki keyakinan tentang perasaannya adalah individu yang akan berhasil di dalam menghadapi setiap tekanan, karena memiliki kepekaan yang lebih baik mengenai perasaan mereka atas pegambilan keputusan pribadi. Sebaliknya, ketidakmampuan dalam mencermati perasaan diri yang sebenarnya membuat individu berada dalam kendali perasaan. Hal tersebut dapat terjadi dikarenakan efek mayoritas karyawan yang diteliti memiliki tingkat kecerdasan emosi yang sederhana, dalam penelitian Salim dan Nasir (2010) mengatakan bahwa tingkat pendidikan akan mempengaruhi tingkat kecerdasan emosi seseorang. Tingkat pendidikan mayoritas karyawan dalam penelitian ini yaitu SMA/sederajat, ini memungkinkan kecerdasan emosi khususnya selfawareness kurang memberikan dampak yang berarti kepada kemampuan 
karyawan tersebut mengatasi stres kerja. Akan tetapi, jika setiap karyawan memiliki self-awareness yang tinggi maka itu dapat membantu mereka dalam mengenali berbagai sumber yang dapat menyebabkan stres kerja.

Berdasarkan pengujian hipotesis yang dilakukan, terdapat 5 variabel yang tidak berpengaruh secara signifikan terhadap stres kerja. Variabel tersebut diantaranya optimism, dan hope yang merupakan dimensi variabel psychological capital. Sementara self-management, social awareness, dan relationship management merupakan dimensi variabel kecerdasan emosi. Variabel optimism menunjukan tidak ada pengaruh yang signifikan terhadap stres kerja. Hasil penelitian ini serupa dengan penelitian yang dilakukan Hayes (2007) yang menyatakan tidak terdapat hubungan yang signifikan antara optimism dan stres kerja. Optimism merupakan suatu pemikiran dimana individu mengatribusikan kejadian positif ke dalam diri sendiri, bersifat tetap, dan penyebabnya bersifat pervasive, dan di lain hal menginterpretasikan kejadian negatif kepada aspek eksternal, bersifat sementara, dan merupakan faktor yang disebabkan situasi tertentu (Luthans, Youssef, \& Avolio, 2007). Optimism merupakan hal penting yang harus dimiliki setiap karyawan karena terkadang mereka mendapati berbagai situasi yang muncul dalam pekerjaan, seperti mendapat teguran dari atasan, atau mereka diminta memenuhi target produksi dan situasi ini dapat menimbulkan stres. Namun, jika karyawan memiliki optimism yang tinggi mereka akan menganggap hal tersebut sebagai hal positif yang dapat menjadi pemicu untuk meraih keberhasilan dalam pekerjaan, karena individu yang optimis akan menyambut setiap tantangan dan menikmati hasil atas prestasi yang dicapai.

Selanjutnya, variabel hope yang menunjukan tidak berpengaruh secara signifikan terhadap stres kerja. Hasil penelitian ini tidak sesuai dengan penelitian yang dilakukan oleh Herbert (2011) yang menyatakan terdapat hubungan yang secara negatif signifikan antara hope dan stres kerja. Hope merupakan kondisi motivasi positif yang didasari oleh interaksi akan perasaan sukses melalui agency (tekad untuk mencapai tujuan) dan pathways (perencanaan untuk mencapai tujuan) (Luthans, Youssef, \& Avolio, 2007). Hope sendiri sangat penting dimiliki oleh setiap individu karena akan membantu menciptakan jalur alternatif ke tujuan yang diinginkan saat tujuan tersebut terhambat. Saat bekerja karyawan sering kali dihadapkan kepada tuntutan yang diminta oleh atasan dan perusahaan. Dampaknya karyawan akan menghabiskan waktu berjam-jam di tempat kerja serta menghabiskan waktu memikirkan bagaimana cara memenuhi tuntutan yang ingin dicapai oleh perusahaan dan hal tersebut membuat 
mereka rentan terkena stres. Saat situasi seperti ini, karyawan yang memiliki hope tinggi mampu mengendalikan diri dan berpikir kreatif sehingga dapat merancang beberapa alternatif pilihan pemecahan masalah untuk mencapai tujuan dalam pekerjaan mereka.

Hasil penelitian dari variabel kecerdasan emosi menunjukkan bahwa tidak terdapat pengaruh yang signifikan pada dimensi self-management terhadap stres kerja. Hasil penelitian ini mendukung penelitian yang dilakukan oleh Salim dan Nasir (2010) yang menyatakan tidak terdapat hubungan yang signifikan antara self-management dan stres kerja. Selfmanagement merupakan kemampuan untuk bertanggung jawab terhadap emosi sendiri dan bagaimana itu berpengaruh terhadap keputusan serta perilaku diri sendiri (Cherniss \& Goleman, 2001). Individu yang memiliki kemampuan self-management lebih mampu dalam menghibur diri sendiri, melepaskan kecemasan, atau kemurungan. Kemampuan self-management sangat penting dimiliki oleh setiap karyawan karena beban pekerjaan yang cukup tinggi dan tanggung jawab yang besar sehingga karyawan akan mudah lelah. Dalam situasi seperti ini, emosi karyawan akan lebih mudah terbawa dan akhirnya muncul tekanan atau stres kerja. Akan tetapi, jika karyawan memiliki kemampuan self-management yang baik maka karyawan tersebut tidak akan mudah terbawa emosi serta akan terhindar dari stres kerja.

Hasil penelitian dari variabel kecerdasan emosi menunjukkan bahwa tidak terdapat pengaruh yang signifikan pada dimensi social awareness terhadap stres kerja. Hasil penelitian ini mendukung penelitian yang dilakukan oleh Salim dan Nasir (2010) yang menyatakan tidak terdapat hubungan yang signifikan antara social awareness dan stres kerja. Social awareness merupakan kemampuan untuk mengenali, merasakan atau membaca emosi orang lain (Cherniss \& Goleman, 2001). Individu yang memiliki kemampuan dibidang ini akan lebih mampu merasakan emosi orang lain, mampu membaca situasi yang terjadi sehingga mampu bertindak dengan tepat. Dalam hal ini, karyawan yang bekerja di dalam perusahaan memiliki kecenderungan untuk lebih sering berinteraksi dengan banyak orang, seperti rekan kerja, atasan, dan sebagainya. Karyawan yang memiliki social awareness yang tinggi akan lebih mampu mengenali dan memahami karakter orang lain sehingga terjadinya kesalahpahaman atau timbulnya konflik yang dapat menyebabkan stres akan rendah.

Hasil penelitian dari variabel kecerdasan emosi menunjukkan bahwa tidak terdapat pengaruh yang signifikan pada dimensi relationship management terhadap stres kerja. Hasil penelitian ini mendukung penelitian yang dilakukan oleh Salim dan Nasir (2010) yang menyatakan 
tidak terdapat hubungan yang signifikan antara relationship management dan stres kerja. Relationship management merupakan kemampuan untuk menggunakan kesadaran emosi sendiri dan emosi orang lain untuk dapat berhubungan dengan orang lain (Cherniss \& Goleman, 2001). Karyawan yang mampu mengelola relationship management dengan baik cenderung tidak mudah mengalami stres kerja. Ketika karyawan tersebut mengalami stres di tempat kerja yang menyebabkan gangguan fisik, psikis dan perilaku maka karyawan tersebut akan segera mampu mengenali dan mencari solusi untuk mengatasinya dengan memanfaatkan dukungan sosial yang diperoleh dari kemampuannya menjalin hubungan dengan orang lain.

\section{Saran}

Peneliti menyadari bahwa masih banyak kekurangan dan keterbatasan dalam penelitian ini sehingga dibutuhkan penelitian lebih lanjut untuk melengkapi kekurangan dan keterbatasan tersebut. Berdasarkan hasil penelitian yang diperoleh, peneliti membagi saran menjadi dua, yaitu saran teoritis dan saran praktis. Saran tersebut dapat dijadikan bahan pertimbangan bagi peneliti lain yang akan meneliti variable dependent yang sama.

\section{Saran Teoritis}

Berdasarkan hasil analisis regresi, sumbangan efektif dari hasil penelitian pada variabel self-efficacy, resiliency, dan self-awareness terhadap stres kerja menunjukkan pengaruh secara keseluruhan sebesar $16,1 \%$ dan selebihnya dipengaruhi oleh variabel lain. Pada penelitian selanjutnya disarankan agar melakukan penelitian untuk menguji faktor lain yang mempengaruhi stres kerja seperti kepuasan kerja (Fillion et al, 2007), komitmen organisasi (Aghdasi et al., 2011), dan kepribadian (Costa \& McCrae, 1990). Terdapat beberapa faktor lain yang perlu diperhatikan juga seperti beban kerja, salary, usia, jenjang karir, dan dukungan organisasi, serta budaya organisasi. Mempertimbangkan variabel tersebut, diharapkan penelitian selanjutnya akan lebih menyempurnakan hasil penelitian ini.

Tidak signifikannya beberapa variabel seperti optimism, hope, selfmanagement, social awareness, dan relationship management diasumsikan oleh peneliti berkaitan dengan jumlah sampel dan tingkat pendidikan. Diharapkan, bagi penelitian selanjutnya yang tertarik meneliti stres kerja agar menentukan sampel dengan jumlah yang lebih besar dan lebih bervariasi dari segi pendidikan. Hal ini dimaksudkan agar terlihat hasil yang lebih baik dan dapat dibandingkan tingkat stres kerja pada karyawan di perusahaan. 


\section{Saran Praktis}

Kesimpulan penelitian ini menunjukkan bahwa variabel self-efficacy berpengaruh secara signifikan $(p<0.05)$ terhadap stres kerja. Bagi karyawan diharapkan lebih memiliki kesadaran akan kemampuan yang dimiliki di dalam dirinya sendiri, memiliki sikap optimis dan keyakinan yang positif terhadap diri sendiri, serta memiliki tanggung jawab terhadap pekerjaan yang dilakukan.

Kesimpulan penelitian ini menunjukkan bahwa variabel resiliency berpengaruh secara signifikan $(p<0.05)$ terhadap stres kerja. Bagi karyawan diharapkan lebih memiliki penilaian realistis terhadap berbagai masalah yang terjadi, lebih berpikiran positif, memiliki emosi positif untuk meningkatkan dan mengembangkan diri, mampu mengendalikan emosi saat berada dalam tekanan, serta mampu menciptakan strategi coping ketika terjadi kemunduran.

Kesimpulan penelitian menunjukkan variabel self-awareness berpengaruh secara signifikan $(p<0.05)$ terhadap stres kerja. Bagi karyawan diharapkan lebih sadar tentang perasaan sendiri, mampu mengendalikan emosi negatif yang muncul, dan mampu mengenali berbagai macam emosi sehingga dapat memberikan respon emosi yang tepat serta mampu menghindari ketakutan yang berlebih mengenai apa yang dapat dilakukan diri sendiri dalam pekerjaan.

Bagi perusahaan diharapkan dapat terus mempertahankan psychological capital dan kecerdasan emosi karyawan dengan cara memberikan training atau pelatihan kepada karyawan seperti memberikan training pengenalan emosi, training motivasi positif, training pengembangan potensi diri, dan memberikan ruangan khusus bagi karyawan yang ingin melakukan konseling, serta melakukan aktivitas di luar perusahaan seperti outbound. Selain itu, dalam pelaksanaan rekruitmen calon karyawan, perusahaan diharapkan lebih memperhatikan aspek kepribadian setiap calon karyawan. Diharapkan dengan berbagai hal tersebut dapat membantu karyawan untuk lebih mampu dalam menghindari dan mengatasi munculnya stres di tempat kerja serta mampu meningkatkan mutu sumber daya manusia yang berkualitas. 


\section{DAFTAR PUSTAKA}

Aghdasi, S., Kiamanesh, A. R., Ebrahim, A. N. (2011). Emotional intelligence and organizational commitment: Testing the mediatory role of occupational stress and job satisfaction. International Conference on Education and Educational Psychology (ICEEPSY 2011).

Augusto L. J. M., Lopez-Zafra, E., Berrios Martos, M. P. \& Aguilar-Luzon, M. C. (2008). The relationship between emotional intelligence, occupational stress and health in nurses: A questionnaire survey. International Journal of Nursing Studies, 45(6), 888-901.

Avey, J. B., Luthans, F., \& Jensen, S. M. (2009). Psychological capital: a positive resource for combating employee stress and turnover. Human Resource Management, 48(5), 677-693.

Avey, J. B., Patera, J. L., \& West. B. J. (2006). The Implications of Positive Psychological Capital on Employee Absenteeism. University of NebraskaLincoln.

Bauer, T. N., Bodner, T., Erdogan, B., Truxillo, D. M., \& Tucker, J. S. (2007). Newcomer adjustment during organizational socialization: A metaanalytic review of antecedents, outcomes, and methods. Journal of Applied Psychology, 92(3), 707-721.

Chang, C., Chang, F. (2010). Relationships among traditional Chinese personality traits, work stress, and emotional intelligence in workers in the semiconductor industry in Taiwan. Springer Science Business Media, 44:733-748

Cherniss, C., \& Goleman, D. (2001). The emotionally intelligent workplace. San Fransisco, CA: Jossey-Bass

Ciarrochi, J., Deane, F., Anderson, S. (2002). Emotional intelligence moderates the relationship between stress and mental health. Personally and Individual Differences, 28, 539-561.

Colligan, T. W., \& Higgins, E. M. (2005). Workplace stress etiology and consequences. Journal of Workplace Behavioral Health, 21(2), 89-97.

Costa, P. T., Jr., \& McCrae, R. R. (1990). Personality: Another "hidden factor" in stress research. Psychological Inquiry, 1(1), 22-24.

Coutu, D. L. (2002). How resilience works. Diunduh pada tanggal 20 November 2013 dari http://hbr.org/2002/05/how-resilience-works/

Fillion, L., Tremblay, I., Manon, T., Cote, D., Struthers, C. W., \& Dupuis, R. (2007). Job satisfaction and emotional distress among nurses providing palliative care: Empirical evidence for an integrative occupational stressmodel. International Journal of Stress Management, 14(1), 1-25.

Harris, G. E., \& Cameron, J. E. (2005). Multiple dimensions of organizational identification and commitment as predictors of turnover intentions and psychological well-being. Canadian Journal of Behavioural Science, 37(3), 159-169.

Hayes, C. T., \& Weathington, B. L. (2007). Optimism, Stress, Life Satisfaction, 
and Job Burnout in Restaurant Managers. The Journal of Psychology, 141(6), 565-579.

Herbert, M. (2011). An Exploration Of The Relationships Between Psychological Capital (Hope, Optimism, Self-efficacy, Resiliency), Occupational Stress, Burnout And Employee Engagement (Thesis). The University Of Stellenbosch.

Lazarus, R. S., \& Folkman, S. (1984). Stress, appraisal, and coping. New York: Springer.

Luthans, F. (2011). Organizational behavior: An evidence-based approach. New York: McGraw-Hill.

Luthans, F., Avey, J. B., \& Patera, J. L. (2008). Experimental analysis of a webbased intervention to develop positive psychological capital. Academy of Management Learning and Education, 7(2), 209-221.

Luthans, F., Avolio, B., Avey, J. B., \& Norman, S. M. (2007). Psychological capital: Measurement and relationship with performance and satisfaction. Personnel Psychology, 60(3), 541-572.

Luthans, F., Norman, S. M., Avolio B. J., \& Avey J. B. (2008). The mediating role of psychological capital in the supportive organizational climate employee performance relationship. Journal of Organizational Behavior. 29, 219-238.

Luthans, F., Youssef, C. M., \& Avolio, B. J. (2007). Psychological capital: Developing the human competitive edge. New York: Oxford University Press.

Marino, S. (2004). The stress epidemic. Industry Week. Diunduh pada tanggal 20 November 2013 dari http://www.industryweek.com/

Mikail, Bramirus. (2011). 30 Persen Pekerja Kantor Alami Stres. Diunduh pada tanggal 4 Oktober 2013 dari http://health.kompas.com/

Quick, J. C., Quick, J. D., Nelson, D. L., \& Hurrell, J. J. Jr. (1997). Organizational Development; Organizations; Prevention; Psychodiagnosis; Stress Management. Washington, DC, US: American Psychological Association.

Robbins, S. P., \& Judge, T. A. (2013). Organizational Behavior. London: Pearson Education Limited.

Salim, S. S. S., \& Nasir, R. (2010). Kesan kecerdasan emosi ke atas tekanan kerja dan niat berhenti kerja profesion. 5(1), 53-68.

Salovey, P., \& Mayer, J.D. (1990). Emotional intelligence. Imagination, Cognition, and Personality, 9, 185-211.

Siu, O., Hui, C., Phillips, DR., Lin, L., Wong, T. W., \& Shi, K. (2009). A study of resiliency among Chinese health care workers: capacity to cope with workplace stress. Journal of Research in Personality, 43(5), 770-776.

Siu, O., Spector, P. E., \& Cooper, C. J. (2005). Work stress, self-efficacy, Chinese work values, and work well-being in Hong Kong and Beijing. International Journal of Stress Management, 12(3), 274-288.

Slaski, M., \& Cartwright, S. (2003). Emotional intelligence training and it simplications for stress, health and performance. Stress and Health, 19, 
233-239.

Totterdell, P., Wood, S., \& Wall, T. (2006). An intra-individual test of the demandscontrol model. Journal of Occupational and Organizational Psychology, 79(12), 63-85.

Weinberg, A., Sutherland, V. J., \& Cooper, G. (2010). Organizational stress management: A strategic approach. UK: Palgrave Macmillan.

Youssef, C. M., \& Luthans, F. (2007). Positive organizational behavior in the workplace: The impact of hope, optimism, and resilience. Journal of Management, 33(5), 774-800. 